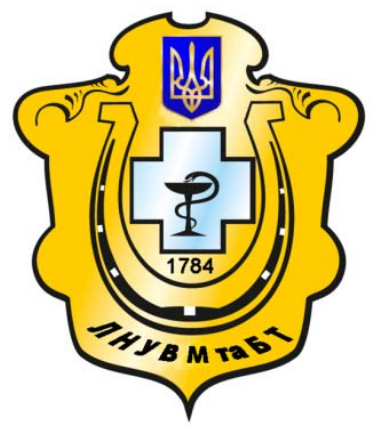

Науковий вісник Львівського національного університету ветеринарної медицини та біотехнологій імені С.З. Гжицького

Scientific Messenger of Lviv National University of Veterinary Medicine and Biotechnologies named after S.Z. Gzhytskyj

doi:10.15421/nvlvet6647

ISSN 2413-5550 print

ISSN 2518-1327 online

$\underline{\text { http://nvlvet.com.ua/ }}$

UDC 619

\title{
Factor VII deficiency in Polish Hound - accidental event or new permanent risk?
}

\author{
A. Milczak, D. Bochyńska, B. Abramowicz, M. Staniec, K. Buczek, I. Balicki \\ tatotiny@o2.pl
}

Universityof Life Sciences in Lublin, Veterinary Medicine Faculty,
Department ofInternal Diseases, Lublin, Poland

\begin{abstract}
The Polish Hound (ogar polski) is a small, old breed of hunting dogs. The breed was recognized by the Fédération Cynologique Internationale (FCI) in 1966.A three-year-old Polish Hound male, was admitted to the Clinic of Internal Diseases of Companion Animals of Life Science University in Lublin because of signs of haemorhagic diathesis. There was no preceding history of trauma. General clinical examination was unremarkable. On initial diagnostic testing prothrombin time (PT)of the patient was prolonged nearly by three times. To characterize the dog's coagulopathy further, samples were collected for coagulation screening tests, mixing studies and factor analyses. Investigations revealed factor VII activity below $2 \%$.Unfortunately we had been unable to determine whether the disorder is inherited or is the result of a spontaneous mutation. It is very likely that the nature of described deficit is inherited. Canine hereditary FVII deficiency was first described in 1962 as an incidental finding in Beagles. Later, the defect was identified in another breeds, such as: English Bulldogs, Alaskan Malamutes, Miniature Schnauzers, Boxers, Scottish Deerhounds, Alaskan Klee Kai Dog and mixed-breed dogs. In 2005 a molecular characterization of FVII deficiency in Beagles was described. Unfortunately we had been unable to determine whether the disorder is inherited or is the result of a spontaneous mutation. To our knowledge this case is the first to report of isolated factor VII deficiency in Polish Hound.
\end{abstract}

Key words: dog, Polish Hound, factor VII, prothrombin time, PT, blood coagulation, bleeding disorders, coagulopathy, hereditary deficiency, genetic diseases.

\section{Citation:}

Milczak, A., Bochyńska, D., Abramowicz, B., Staniec, M., Buczek, K., Balicki, I. (2016). Factor VII deficiency in Polish Hound - accidental event or new permanent risk?. Scientific Messenger LNUVMBT named after S.Z. Gzhytskyj, 18, 2(66), 227-230.

\section{Introduction}

The Polish Hound (ogar polski) is an old, traditional breed of hunting dogs. This breed is considered to have descended from the Kostroma Hound or was developed through crossbreeding of Bloodhounds imported to Poland in the Middle Ages, with local dogs. World War II resulted in the dramatic decline of the Polish Hounds' population. The postwar restoration of Polish Hound were undertaken by Piotr Karwiak. The common dog we see today typically goes back to just two dogs and two bitches brought over to Poland in 1959 from Lithuania territory. The breed was recognized by the Fédération Cynologique Internationale (FCI) in 1966.The current population of Polish Hounds is estimated at 1000 animals (Głażewska, 2008; Głażewska and Prusak, 2012; Książek et al., 2014). Unfortunately the low number of the founders may result in the decreasing of genetic variability and in consequence declining health condition of the breed (Frankham, 1996). This can be seen as, for instance, smaller size of litter, increased neonatal death or high frequency of genetic disease. A classic example of such problems is population of Dobermans where approximately $30 \%$ of dogs are affected with von Willebrand's disease, $50 \%$ are carriers of the vWD gene and only $20 \%$ of Dobermans are completely clear of the disease gene (Mostoskey et al., 2000). What is the incidence of genetic diseases in Polish Hounds? It is difficult to assess the incidence of such diseases in this breed for the lack of the database and due to the unwillingness to provide information by breeders and dog owners. So far only the occurrence of entropion condition in Polish Hounds has been described by Łuczak and Balicki (Książek et al., 2014).

Case study. A three-year-old Polish Hound male, registered in the Introductory Book (father of this dog registered in the Polish Pedigree Book and mother in the Introductory Book) was admitted on 16th May 2016 to the Clinic of Internal Diseases of Companion Animals of Life Science University in Lublin because of hyphaema formation in anterior chamber of the eye. The patient was reffered from the surgical ward,where had been treated 
earlier due to suspicion of uveitis. Topical ophthalmic drugs and orally non-steroidal anti-inflammatories were administered over two weeks without improvement. There was no preceding history of trauma. General clinical examination was unremarkable. Physical exam of the skin and mucous membranes revealed no hemorrhages or other hemorrhagic symptoms however excessive bleeding was noted at phlebotomy sites. Abdominal ultrasound did not reveal any significant abnormalities. To characterize the dog's status further, blood samples were collected for $\mathrm{CBC}$, biochemistry andcoagulation screening tests.The CBC parametersand basic serum biochemistry profile (urea $37.12 \mathrm{mg} / \mathrm{dl}$, glucose 98.3 $\mathrm{mg} / \mathrm{dl}$, GPT $23 \mathrm{U} / \mathrm{l}$ )of the patient were within normal ranges. On initial diagnostic testing platelet count and activated partial thromboplastin time (APTT) both were within normal limits. Platelet function as measured by the PFA-200 was correct.

Only prothrombin time (PT) was prolonged nearly by three times. Ingestion of an anticoagulant was suspected, although the dog-owner denied accidental ingestion of rat poison by the dog.

Initial $\mathrm{CBC}$ and coagulation panel of the patient (the day 0 ).

Tab. 1

\begin{tabular}{|l|c|c|c|l|c|c|c|}
\hline Parameter & units & Result & Normal range & Parameter & units & Result & Normal range \\
\hline WBC & $10^{9} / 1$ & 6.8 & $6.0-12.0$ & PT & s & 34.2 & $8.0-12.0$ \\
\hline RBC & $10^{12} / 1$ & 6.19 & $5.50-8.50$ & Wsk. PT & $\%$ & 37 & \\
\hline HCT & $\%$ & 44.0 & $44.0-57.0$ & INR & - & 2.86 & $0.8-1.2$ \\
\hline HGB & $\mathrm{g} / \mathrm{dl}$ & 16.1 & $15.0-20.0$ & APTT & $\mathrm{s}$ & 13.1 & $12.0-25.0$ \\
\hline MCV & $\mathrm{fl}$ & 71 & $60-77$ & APTT Ratio & - & 0.37 & - \\
\hline $\mathrm{MCH}$ & $\mathrm{pg}$ & 25.9 & $17.0-26.0$ & Fibrinogen & $\mathrm{mg} / \mathrm{dl}$ & 300 & $150-350$ \\
\hline $\mathrm{MCHC}$ & $\mathrm{g} / \mathrm{dl}$ & 36.5 & $31.0-38.0$ & & & & \\
\hline RDW $\%$ & $\%$ & 15.6 & $14.0-17.0$ & COL/ADP & $\mathrm{s}$ & 53 & $50.0-80.0$ \\
\hline PLT & $10^{9} / 1$ & 280 & $200-460$ & COL/EPI & $\mathrm{s}$ & 110 & $80.0-120.0$ \\
\hline
\end{tabular}

To correct presumed deficiency of the vitamin $\mathrm{K}$, the dog was treated with orally vitamin $\mathrm{K}$ (Vitakon $1 \mathrm{mg} / \mathrm{kg}$ PO SID) for one week. At that time the dog was clinically normal. The hyphema resolved completely but administration of vitamin $\mathrm{K}$ had no effect on PT. It was even longer (41.5 s; INR 3.52) than at presentation. In such condition, hereditary coagulation factors deficiency or presence of coagulation factors inhibitors were suspected as the cause of coagulopathy. To characterize the dog's coagulopathy further, samples were collected for coagulation screening tests, mixing studies and factor analyses.

Coagulation Assays. Coagulation assays were performed on fresh citrate plasma samples with an APTT reagent, and a PT reagent (Bio-Ksel, Toruń, Poland), in an automatic coagulation analyzer, Bioksel6000 (Bio-Ksel, Toruń, Poland). All assays utilized human lyophilised plasma (Bio-Ksel, Torun, Poland) for the preparation of the calibration and QC. All the required materials are commercially available.

Mixing studies. Mixing studies were performed to detect a potential circulating inhibitor.

Immediate mixing studies. Pooled dog's normal platelet poor plasma (NPP prepared from 20 healthy dogs) and patient plasma were mixed at a ratio of $1: 1$. Immediately after preparation, the PT of the $1: 1 \mathrm{mix}$ was tested in the coagulation analyzer and clotting time was recorded.
Incubated mixing studies. Normal citrated (NPP) and test plasma were mixed in a1:1 ratio and after $2 \mathrm{~h}$ at $37{ }^{\circ} \mathrm{C}$ incubation period the PT of the mix was determined in an automated coagulation analyzer.

Assays for coagulation factors $V$ and VII. Coagulation factor V and VII activities were measured by one stage PT-derived assay in which the ability of the patient's plasma to normalize the prolonged clotting time of specific factor-deficient human plasma was determined (Zondag et al., 1985; Friederich, et al., 2003). The results were expressed as a percentage of factors activity in standard human plasma which had an assigned value of $100 \%$.

\section{Results}

Table 2 shows the results obtained for different coagulation tests in patient's blood samples collected at the day +8 after admission. Activated Partial Thromboplastin Time (APTT) and fibrinogen levels were normal. The patients had only isolated PT prolongation.Both types of mixing studies corrected the initially prolonged PT to normal range. Further investigations revealed factor VII activity below $2 \%$. Factor V assay was normal. After 34 days factor VII level was higher $(4.32 \%)$.

Results of coagulation assays (the day +8 ).

Tab. 2

\begin{tabular}{|l|c|c|c|c|c|c|}
\hline Parameter & units & NPP & Patient plasma & Immediate mixing studies & Incubated mixing studies & Normal range \\
\hline PT & {$[\mathrm{s}]$} & 9.1 & 43.5 & 13.2 & - & 12.3 \\
\hline APTT & {$[\mathrm{s}]$} & 12.8 & 13.5 & - & - & $-12.0-25.0$ \\
\hline Factor V & $\%$ & 482 & 468 & - & - & - \\
\hline Factor VII & $\%$ & 350 & $<2 \%$ & - & - & - \\
\hline Fibrinogen & $\mathrm{mg} / \mathrm{dl}$ & 212 & 260 & -500 & - \\
\hline
\end{tabular}




\section{Discussion}

Factor VII is a vitamin $\mathrm{K}$-dependent serine protease glycoprotein with a pivotal role inextrinsic pathway of coagulation. It is, as most of clotting factors, synthesized in the liverand secreted as a single-chain glycoprotein of $48 \mathrm{kD}$. The gene coding factor VII is located in humans on band 13at position q34 (Mariani et al., 2005; Callan et al., 2006). The first case of isolated factor VII deficiency in a child was described by Alexander in 1951 (Alexander et al., 1951). Inherited factor VII (FVII) deficiency is a rare autosomal recessive hemorrhagic disorder prevalence of which it is estimated to be 1 case per 500,000 persons in the general population (Friederich et al., 2003; Mariani et al., 2005). So far more than 100 mutations, have been identified in the human factor VII gene (Mariani et al., 2005). Inherited factor VII deficiency can be classified as type 1 (decreased biosynthesis) or type 2 (dysfunctional pattern) (Tuddenham et al., 1995). It can result in mild to moderate blood clotting disorder. Clinical bleeding can widely vary and does not always correlate with the level of factor VII coagulant activity measured in plasma.

Canine hereditary FVII deficiency was first described in 1962 as an incidental finding in Beagles (Aljamali et al., 2005). Later, the defect was identified in another breeds, such as: English Bulldogs, Alaskan Malamutes, Miniature Schnauzers, Boxers, Scottish Deerhounds, Alaskan Klee Kai Dogand mixed-breed dogs (Callan et al., 2006; Kaae et al., 2007). Until recently factor VII deficiency could only be diagnosed by measuring the level of factor VII in the blood. In 2005, Aljamaliand coworkers (Aljamali et al., 2005). described a molecular characterization of FVII deficiency in Beagles. It was a mutation located in exon 5 resulting in the substitution of glycine 96 (GGA) to glutamic acid (GAA) in the second epidermal growth factor-like domain (Aljamali et al., 2005). Further researches have shown that the same mutation is responsible for deficiency of FVII in another dog breeds (Kaae et al., 2007). In affected dogs the related clinical signs are typically mild. Excessive bleeding only occurs after a severe trauma or surgery.

In the case described above bleeding signs were rather mild. Primary haemostasis and intrinsic pathway of coagulation were found to be normal. The investigations revealed only prolonged prothrombin time (PT). The PT may be prolonged due to deficiency of one or more clotting factors or due to the presence of an inhibitor that interferes with the normal function of a coagulation factor. Since anticoagulant rodenticide poisoning remains a common health problem among pets in Poland therefore a presumptive diagnosis of toxicosis was made. Mixing studies results allow to exclude the presence of anticoagulant in the circulation as the cause of the coagulopathy. Ultimate diagnosis was made based upon persistent low factor VII activity. Unfortunately we had been unable to determine whether the disorder is inherited or is the result of a spontaneous mutation. It is very likely that the nature of described deficit is inherited because since the 1970's, to improve basic anatomical measures and the declining health condition of the breed, dogs of unknown origin have been used in breeding (Książek et al., 2014). Despite this, it is definitely bad news for Polish
Hound breeders because of high risk of producing affected offspring in the future.

\section{Conclusion}

To our knowledge the case described above is the first to report of isolated factor VII deficiency in Polish Hound. All dogs intended for breeding should be appropriately tested in the future.

\section{References}

Alexander, B., Goldstein, R., Landwehr, G., Cook, C.D. (1951). Congenital SPCA deficiency: a hither to unrecognized coagulation defect with hemorrhage rectified by serum and serum fractions. $\mathrm{J}$ Clin Invest. 30, 596-608.

Aljamali, M.N., Callan, M.-B., Pollak, E.S., Giger, U., Werner, P., Griot-Wenk, M., High, K.A. (2005). Molecular Characterization of Hereditary Factor VII Deficiency in Beagles. Molecular Therapy. 11, 234-235.

Callan, M.B., Aljamali, M.N., Margaritis, P., GriotWenk, M.E., Pollak, E.S., Werner, P., Giger, U., High, K.A. (2006). A novel missense mutation responsible for factor VII deficiency in research Beagle colonies. J. Thromb Haemost. 4, 2616-2622.

Frankham, R. (1996). Relationship of genetic variation to population size in wildlife. Conserv. Biol. 10, 1500 1508.

Friederich, P.W., Henny, C.P., Messelink, E.J., Geerdink, M.G., Keller, T., Kurth, K.H., Büller, H.R., Levi, M. (2003). Effect of recombinant activated factor VII on perioperative blood loss in patients undergoing retropubic prostatectomy: a double-blind placebocontrolled randomised trial. Lancet. 361(9353), 201205.

Głażewska, I., Prusak, B. (2012). Evaluation of the effectiveness of introducing new alleles into the gene pool of a rare dog breed: Polish hound as the example. Czech J. Anim. Sci. 57, 248-254.

Głażewska, I. (2008). Genetic diversity in Polish hounds estimated by pedigree analysis. Livestock Sci. 113, 296-301.

Kaae, J.A., Callan, M. B., Brooks, B.M. (2007). Hereditary Factor VII Deficiency in the Alaskan Klee Kai Dog. J. Vet. Intern. Med. 2, 976-981.

Książek, M., Gruszczyńska, J., Grzegrzółka, B. (2014). Problems in cooperation with breeders and dog owners on the example of entropion frequency estimation in polish hounds. Acta Sci. Pol., Zootechnica. 13, 81-92.

Mariani, G., Herrmann, F.H., Dolce, A., Batorova, A., Etro, D., Peyvandi, F., Wulff, K., Schved, J.F., Auerswald, G., Ingerslev, J., Bernardi, F. (2005). Clinical phenotypes and factor VII genotype in congenital factor VII deficiency.Thromb Haemost. 93, 481-487.

Mischke, R. (1994). MethodischeAspekte für die koagulometrische Aktivitätsbestimmung der Gerinnungsfaktoren II, V, VII und X aus Hunde plasma [Methodological aspects for the determination of the coagulative activity of coagulation factors II, V, 
VII and X from dog plasma]. Zentralbl Veterinarmed A. 41, 431-442.

Mostoskey, U.V., Padgett, G.A., Stinson, A.W., Duffendack, J.C. (2000). Canine Molecular Genetic Diseases. Compendium on Continuing Education for the Practising Veterinarian-North American Edition. $22,480-489$.
Tuddenham, E.G., Pemberton, S., Cooper, D.N. (1995). Inherited factor VII deficiency: genetics and molecular pathology. Thromb Haemost. 74, 313-321.

Zondag, A.C.P., Kolb, A.M., Bax, N.M.A. (1985).

Normal Values of Coagulation in Canine Blood. Haemostasis 15, 318-323.

Стаття надійшла до редакиії 1.09.2016 